\title{
Bullous Systemic Lupus Erythematosus
}

\author{
Fadwa Mekouar, Salaheddine Hammi, Naoual Elomri and Driss Ghafir
}

Key words: arthralgia, bubbles, lupus

(Intern Med 50: 1445, 2011)

(DOI: 10.2169/internalmedicine.50.4887)

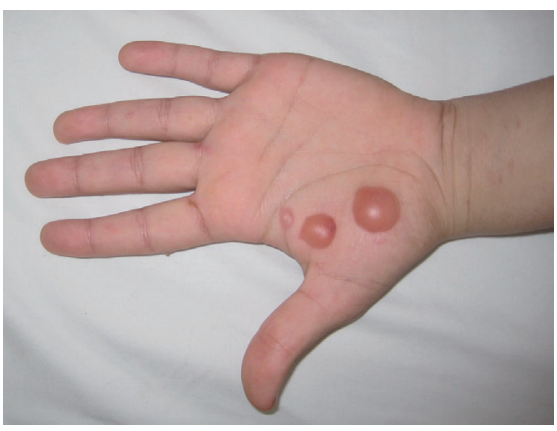

Picture 1.

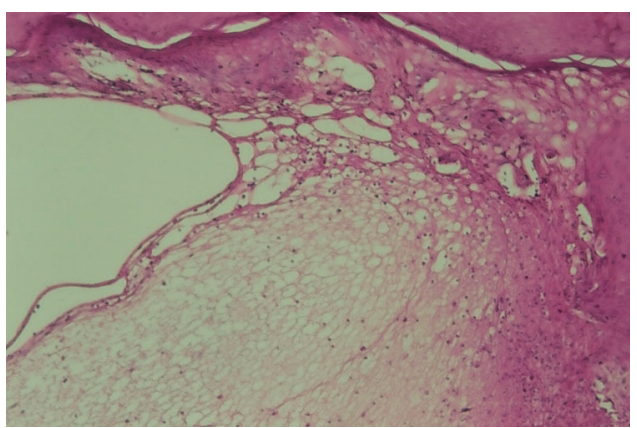

Picture 2.

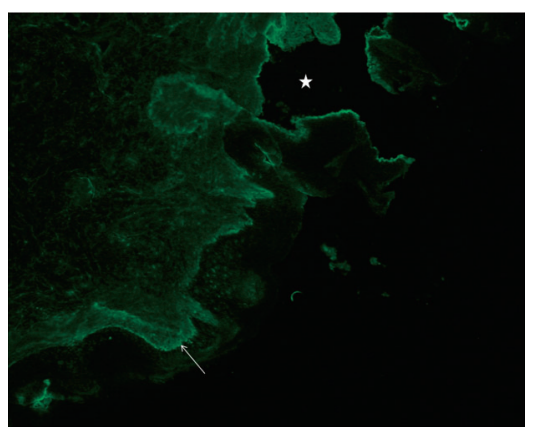

Picture 3.
A 22-year-old woman presented to the internal medicine department with a 2 month history of progressive blistering eruption. She also complained of arthralgias and lower limb edema. Physical examination found blisters on her hands (Picture 1) and feet. Skin biopsy showed subepidermal blister with polymorphous inflammatory infiltrate (Picture 2). Direct immunofluorescence demonstrated linear deposits of IgG, IgM and complement at the dermoepidermal junction (Picture 3). Anti-nuclear antibody was positive. Complement components were decreased. Anti-double stranded DNA antibody was elevated. The patient was anemic. As she had proteinuria and hypoalbuminemia, a kidney biopsy was performed which showed changes consistent with class VI lupus nephritis. The diagnosis of bullous systemic lupus was made. The patient was treated with Mycophenolate mofetil and methylprednisolone pulses relayed by oral prednisone with a clinical improvement of the skin and renal lesions.

Bullous lupus erythematosus is a rare autoimmune disease. The diagnostic criteria were proposed by Camisa and Sharma in 1983 (1). Dapsone is the essential treatment for lupus to control bullous skin lesions. Steroids and immunosuppressive drugs prescribed in cases of associated visceral lesions are equally effective for skin lesions (2).

The authors state that they have no Conflict of Interest (COI).

\section{References}

1. Camisa C, Sharma HM. Vesiculobullous systemic lupus erythematosus. J Am Acad Dermatol 9: 924-933, 1983.

2. Vassileva S. Bullous systemic lupus erythematosus. Clin Dermatol 22: 129-138, 2004.

Internal Medicine B, Mohammed V Military Teaching Hospital, Morocco

Received for publication November 24, 2010; Accepted for publication December 26, 2010

Correspondence to Dr. Fadwa Mekouar, fadmek2000@hotmail.com

(C) 2011 The Japanese Society of Internal Medicine Journal Website: http://www.naika.or.jp/imindex.html 